\title{
エポキシ樹脂の構造制御による高機能化
}

\author{
原田 美由紀 *
}

\section{Functionalization of Epoxy Resins by Control of Their Structures}

\author{
Miyuki HARADA*
}

* 関西大学化学生命工学部化学・物質工学科 ( T 564-8680 吹田市山手町 3-3-35)

* Department of Chemistry, and Materials Engineering, Faculty of Chemistry, Materials and Bioengineering, Kansai University (3-3-35 Yamate-cho, Suita-shi, Osaka 564-8680)

\section{1. はじめに}

エポキシ樹脂は電子部品用材料に用いられるポリマーの 代表的な一種であり，重合反応によって形成されるネット ワークの構造が, 硬化物性に非常に大きな影響を及ぼす ${ }^{1)}$ 。 その物性バランスの良さから広く用いられてきたが, 近年 の部品の高性能・高機能化に対応したさまざまな要求性能 への取り組みが必要である。

一方筆者らは, メソゲン骨格を有するエポキシ樹脂を用 いて, エポキシ樹脂硬化物の立体構造を精密にコントロー ルする試みを行ってきた。メソゲン骨格エポキシ樹脂は, 特定条件下において規則的に配列する性質を有するため, ネットワークの構造制御が可能であり 2) 5)，ネットワーク ポリマーのさらなる高性能化や従来にない新しい機能の発 現が期待されている。ここではこれらの一部を紹介するこ ととする。

\section{2. メソゲン基の構造とメソゲン骨格エポキシ樹脂の 特徵}

メソゲン骨格エポキシ樹脂は, 液晶を形成する化学構造 (メソゲン基) を有するエポキシ樹脂である。(表 1) 2) 6)。 平板状構造で, 共役性を示すメソゲン基同士が $\pi-\pi$ スタッ キングすることによって自己組織化し, スメクチックやネ マチック液晶などの液晶性を示すものが多い。しかしなが ら, その規則性の高さゆえに高結晶性であり, 融点が高く なる傾向がある。また, メソゲン骨格エポキシ樹脂は硬化 物中においても液晶相を形成する場合がほとんどである。 図 1 にテレフタリリデン型液晶性エポキシ樹脂（表 1 ・ 3 段 目の構造) ノジアミノジフェニルメタン (DDM) 系の硬化過 程における偏光顕微鏡写真を示す ${ }^{7)}$ 。硬化剤の添加によっ て配列性が多少阻害されるため, エポキシモノマーの液晶 温度範囲であっても, 溶融直後は両硬化温度ともに一旦は 等方性液体となる。その後, $190^{\circ} \mathrm{C}$ 硬化系では等方相とし て硬化が完了するが, $165^{\circ} \mathrm{C}$ 硬化系では反応進行に伴う分 子量の増大によってメソゲン基のスタッキングが促進さ
表 1.メソゲン骨格エポキシ樹脂の構造と転移温度

エポキシ樹脂の構造 (OR 間がメソゲン基)

$\mathrm{R}:-\mathrm{CH}_{2}-\underset{\mathrm{O}^{\prime}}{\mathrm{CH}-\mathrm{CH}_{2}}$

$\mathrm{C}$ ：結晶, S ：スメクチック相, $\mathrm{N}$ ：ネマチック相, I : 等方相

れ，ミクロオーダーでの配列領域を有するポリドメイン液 晶の硬化物が得られる。このように硬化反応時の温度条件 を変えることによって，メソゲン基がランダムに存在する 等方性硬化物や局所的に配列したポリドメイン液晶相（ネ マチック，スメクチック）硬化物など，三次元ネットワー クの配列を制御できることがメソゲン骨格エポキシ樹脂の 非常に大きな特徴である。さらには外場（電場・磁場・応 力場）やラビング処理を用いての一軸配向硬化物の調製な ど，マクロスコピックな配列も制御可能である。

ここまで紹介したものは, 主鎖骨格中に一つのメソゲン 基のみが導入されたモノメソゲン型エポキシ樹脂である が, ツインメソゲン型エポキシ樹脂というものも知られて いる。これは, 二つのメソゲン基を柔軟なスペーサーを介 して結合させた構造を有するエポキシ樹脂のことである。 スペーサーの導入によって可動性が向上し, 融点の低下や 強靯性の改善に役立つ。特にスペーサーにメチレン鎖を用 いたときは Even-Odd 効果を示し ${ }^{8)}$, メチレン鎖数が奇数の 時には結晶性が低下するが, 偶数の時には高結晶性となり 融点が非常に高くなる。これは, 二つのメソゲン基の立体 配置が鎖数に大きく依存するためである。 


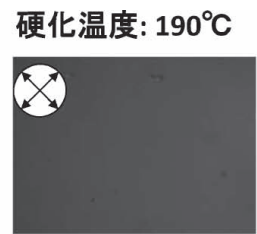

Os

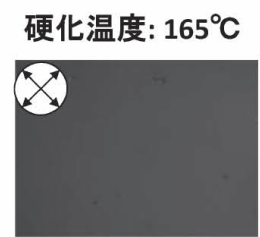

Os

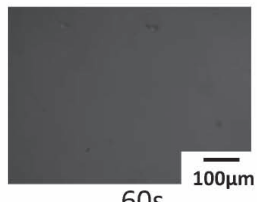

$60 \mathrm{~s}$
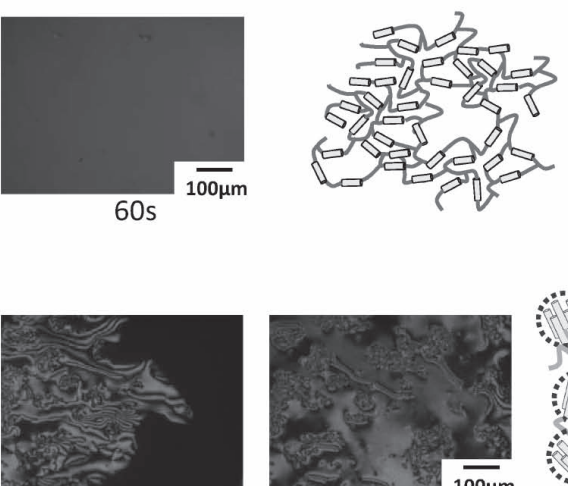

$45 s$
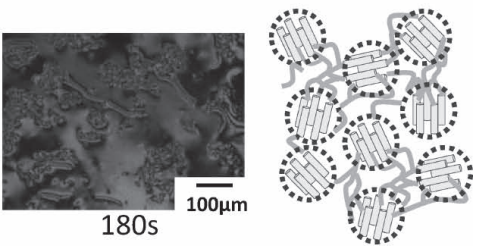

硬化時間

図 1. 液晶性エポキシ樹脂の硬化反応過程における偏光顕微鏡観察

一方，筆者らはシロキサン鎖をスペーサーとして導入し たツインメソゲンエポキシ樹脂を合成した。シロキサン鎖 は可動性の高いエーテル結合を含むことから，アルキル鎖 と比べて融点低下に及ぼす影響が大きく, Even-Odd 効果を 発現しない。トリシロキサンおよび同程度の鎖長のアルキ ル鎖を導入したツインメソゲンエポキシ樹脂を合成したと ころ ${ }^{9}$ ，アルキル型の融点 $192^{\circ} \mathrm{C} に$ 対し，トリシロキサン

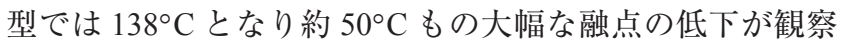
された。また，アルキル型は昇温過程で，シロキサン型は 降温過程で液晶相を示したことから，モノトロピック液晶 であることが確認された。この他にもグリコール鎖などの 柔軟鎖の導入が考えられるが, スペーサーの可動性が大き すぎると，メソゲン基の配列の阻害効果が発現するととも に，硬化物中のスペーサー濃度の増加による $\mathrm{Tg}$ 低下の問 題などが生じるため, 目的の特性に対する最適化が必要で ある。

\section{3. 硬化条件の変化による局所もしくは一軸配向構造 を持つ硬化物の特性}

先にも述べたように，メソゲン骨格エポキシ樹脂の多く は硬化条件や硬化剂の最適化によってネットワーク内に配 列構造を形成でき, この配列性の違いは力学物性に大きく 影響する（表 2)。特に，ポリドメイン液晶相硬化物では等 方相硬化物に比べ，より塑性変形しやすいことが報告され

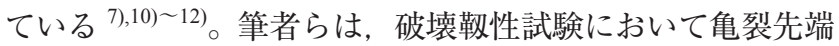
のメソゲン基がより広範囲で再配向することで塑性変形し やすくなり，強勒性が大幅に向上すると考えている。 Ober $^{11)}$ や Carfagna ${ }^{12)}$ なども強勒化機構について提案してい るが, 統一的な見解は得られていない。

一方，硬化温度の多段階変化によって，メソゲンの配列 領域であるドメインの大きさや液晶相形態を制御すること

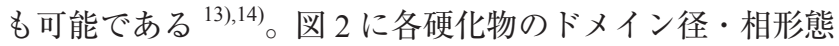
と破壊勒性の関係を示す。等方性硬化物（ドメイン径を 0
表 2. 配列構造の異なるエポキシ樹脂硬化物の強靯性

\begin{tabular}{lc}
\hline \multicolumn{1}{c}{ エポキシ樹脂/硬化剤（相形態） } & $\begin{array}{c}\text { 弾塑性破壊勒性值 } \\
\mathrm{J}_{\mathrm{IC}}(\mathrm{KN} / \mathrm{m})\end{array}$ \\
\hline DGEBA/DDM & $0.27 \pm 0.01$ \\
DGETAM/DDM（等方相・190 $190^{\circ} \mathrm{C}$ 硬化） & $0.55 \pm 0.19$ \\
DGETAM/DDM（ポリドメイン液晶相・ $165^{\circ} \mathrm{C}$ 硬化） & $1.29 \pm 0.08$ \\
\hline
\end{tabular}

*sample shape: $6.0 \times 40 \times 3.0 \mathrm{~mm}$

\section{DGETAM}
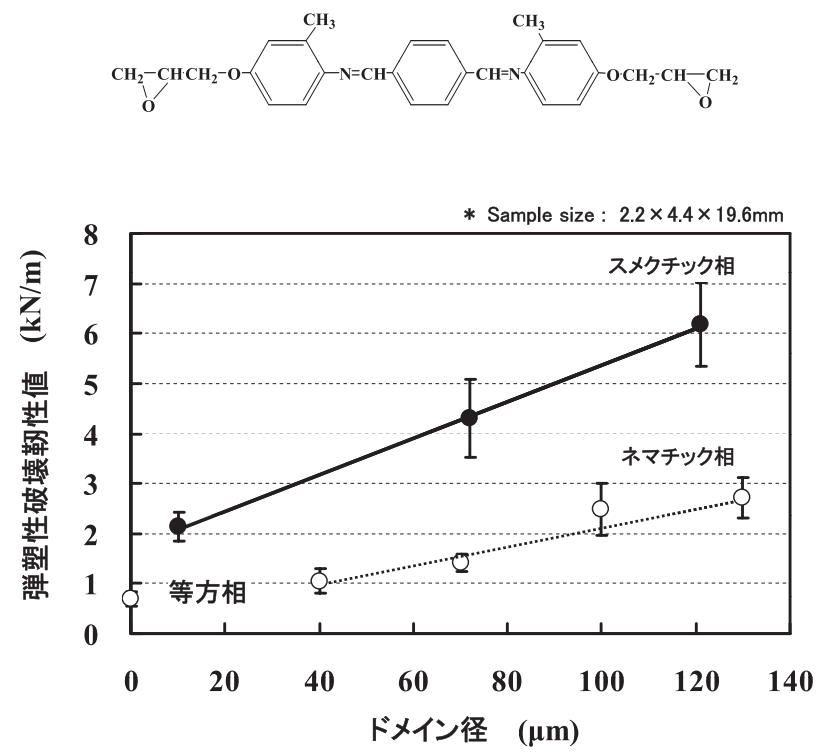

図 2. ポリドメイン硬化物のドメイン径の増大に伴う破壊 勒性変化

$\mu \mathrm{m}$ として表記）と比較すると，ドメイン径の拡大に伴う 破壊勒性值の向上が認められ, 最大で 10 倍もの改善が達成 された。またここの改善効果はドメイン内の配列性が向上 する（内部の液晶配列がネマチック相からスメクチック相 に変化）のに伴って，大きくなることが明らかとなった。 汎用エポキシ樹脂では実現できなかったネットワークの 配列制御は，先述のミクロオーダーのものだけではない。 すなわち，特定方向に配列させたネットワークポリマーを 形成する場合もあり，電場・磁場・応力場，もしくはラビ 
ング法などを利用して硬化させることで構造形成させる試 みが多数報告されている ${ }^{15) ~ 20) 。 B e n i c e w i c z ~ ら ~}{ }^{15)}$ は，スチ ルベン型の液晶性エポキシ樹脂の硬化時に磁場を変化させ ることで, 配向度の異なるネットワークが形成され，12 T 以上では配向度 0.8 の秩序性の高い硬化物が得られること を明らかにした。また, 硬化物の配向度の増加に伴って, 磁場方向の弾性率が急激に増加することを示した。磁場に 沿ってメソゲン基の長軸方向（共有結合方向）が配列した ため高い弾性率を示したものと考えられる。

筆者らもまた, 液晶性エポキシ樹脂を電場や磁場中で硬 化反応させることにより高度に配列したネットワークポリ マーを調製してきた。ラビング処理済みの透明電極間に液 晶性エポキシ樹脂モノマーを封入したセルを調製し，電場 印加条件下で観察したところ ${ }^{17}$, 電場印可前および電圧 2 $\mathrm{V}$ の系では, ポリドメイン構造が観察された。一方, 電圧 $9 \mathrm{~V}$ の系では, 等間隔の明るい縞状模様のウイリアムズド メイン構造を示した。さらに高電圧 $(27 \mathrm{~V})$ では, この縞状 模様が乱れて非定常状態となり, 動的散乱モードとなるこ とが確認された。このことから, 印加電圧 $9 \mathrm{~V}$ の条件で硬 化物を調製した。得られたネットワークの XRD 測定では, 無電場系では均一なデバイ環を形成したのに対して, 電場 印加系では輝点が局所に集約したことから, 電場下で硬化 反応を行うことでネットワークを一軸配列させた硬化物が 調製可能であることが分かった。

また，10 T の磁場中で硬化させることで，メソゲン基長 軸が磁場方向にマクロに配列したスメクチック液晶の異方 性ネットワークを形成できることも報告している ${ }^{18) ~ 20) 。 ~}$ ネットワークの配向度は約 0.7 であり, メソゲン基が磁場 方向に配列した構造となっているが，これはメソゲン基中 に含まれる芳香環の異方性磁化率に起因する。さらに，こ の硬化物はメソゲン基の配列方向に対して， $0.89 \mathrm{~W} / \mathrm{m} ・ \mathrm{~K}$ もの高い熱伝導率を示した ${ }^{18)}$ 。一軸配向ネットワークの共 有結合に沿って熱エネルギを損失なく伝えようとする試み である。しかしながら, 配列に対して直交方向での熱伝導 率は $0.32 \mathrm{~W} / \mathrm{m} \cdot \mathrm{K}$ となった。このように大きな異方性は生 じるものの，ポリドメイン硬化系の $0.43 \mathrm{~W} / \mathrm{m} \cdot \mathrm{K}$ に比べる と, 特定方向のみではあるが大幅に高い熱伝導率を発現さ せることが可能である。また，一般的な高分子材料の熱伝 導率が $0.2 \sim 0.7 \mathrm{~W} / \mathrm{m} \cdot \mathrm{K}^{21)}$ であることを考慮すれば，これ らは非常に優れた熱伝導特性を有していると言える。より 低磁場での硬化を検討したところ, 約 $0.7 \mathrm{~T}$ 以上の磁場下 で硬化反応を行うことで, $10 \mathrm{~T}$ 硬化系とほほ同程度の配向 度を示すネットワークポリマーが得られることが確認され た。

このように単一の樹脂・硬化剤から成る硬化物であるに も関わらず，全く物性の異なるネットワークポリマーを調 製できることがメソゲン骨格エポキシ樹脂の大変興味深い 点である。
表 3. 融点型液晶性エポキシ樹脂 DGEDPC/DDM 系の熱伝導率

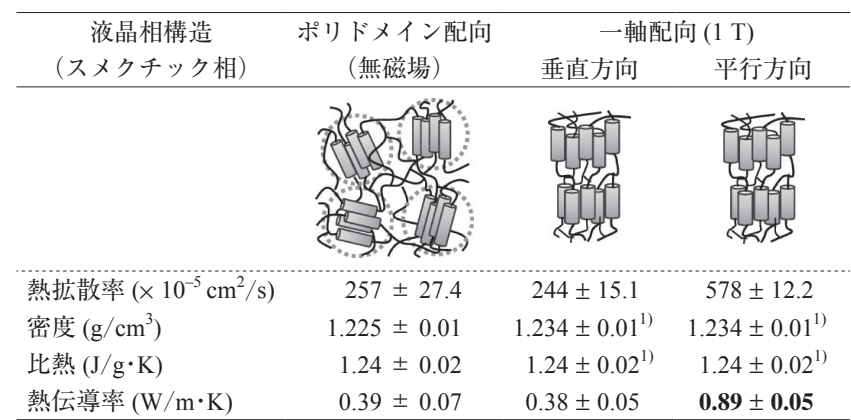

1) 密度と比熱はバルク硬化物を用いて測定

DGEDPC

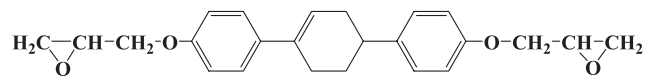

\section{4. 低融点型液晶性エポキシ樹脂の開発}

初めにも述べたように，液晶性エポキシ樹脂は一般に高 融点である。そこで, ターフェニル構造の一部を変化させ たジフェニルシクロヘキセン型エポキシ樹脂 (DGEDPC) を 合成した ${ }^{22)}$ 。その結果, ターフェニル型エポキシ樹脂 (DGETP-Me) の融点 $\left(176^{\circ} \mathrm{C}\right)$ に比べ，大幅な融点降下が確認 された。これによって，比較的低い硬化温度を設定できる ため, 従来の問題点であった高温硬化によるゲル化の速さ を改善できるものと考えられる。また，このモノマーは $95^{\circ} \mathrm{C}$ から $174^{\circ} \mathrm{C}$ でスメクチック $\mathrm{A}$ 相, $199^{\circ} \mathrm{C}$ までネマチッ ク相が確認され, 約 $100^{\circ} \mathrm{C} も の$ 幅広い液晶相温度範囲を有 することが分かった。このような幅広い液晶温度範囲の発 現によって, 硬化温度の選択幅が広がるだけでなく, 再現 性の良い配列構造形成が可能となるものと考えられる。芳 香族アミンを用いて硬化したジフェニルシクロヘキセン型 エポキシ樹脂の熱伝導率（表 3）は, 無磁場硬化のスメク チックポリドメイン硬化物では熱伝導率は $0.39 \mathrm{~W} / \mathrm{m} \cdot \mathrm{K}$ と なり, 汎用のエポキシ樹脂の值 $(0.2 \mathrm{~W} / \mathrm{m} \cdot \mathrm{K})$ に比べ 2 倍ほ どの高い值を示した。さらに $1 \mathrm{~T}$ で磁場硬化したスメク チック一軸配向硬化物では, 配向方向で高熱伝導率が確認 された。この系での配向度は 0.79 となっており, 高配向し た網目鎖の共有結合方向で熱伝達効率が高いことを示すも のと考えられる。

\section{5. 高耐熱性メソゲン骨格エポキシ樹脂}

ここまでは, メソゲン基を用いてのネットワーク構造の 配列性付与による高機能化について述べてきたが，メソゲ ン基の剛直な構造に注目して多官能構造と組み合わせた高 耐熱化への取り組みについても行っているので，いくつか の例について述べる。

まず，分子の中心に四分岐構造を有する 4 官能型テトラ メソゲンエポキシ樹脂を合成し，等方相硬化物の熱的性質 について検討するため, 動的粘弾性測定を行った ${ }^{23)}$ (図 3)。その結果, $250^{\circ} \mathrm{C}$ までの幅広い温度範囲において, ガ 


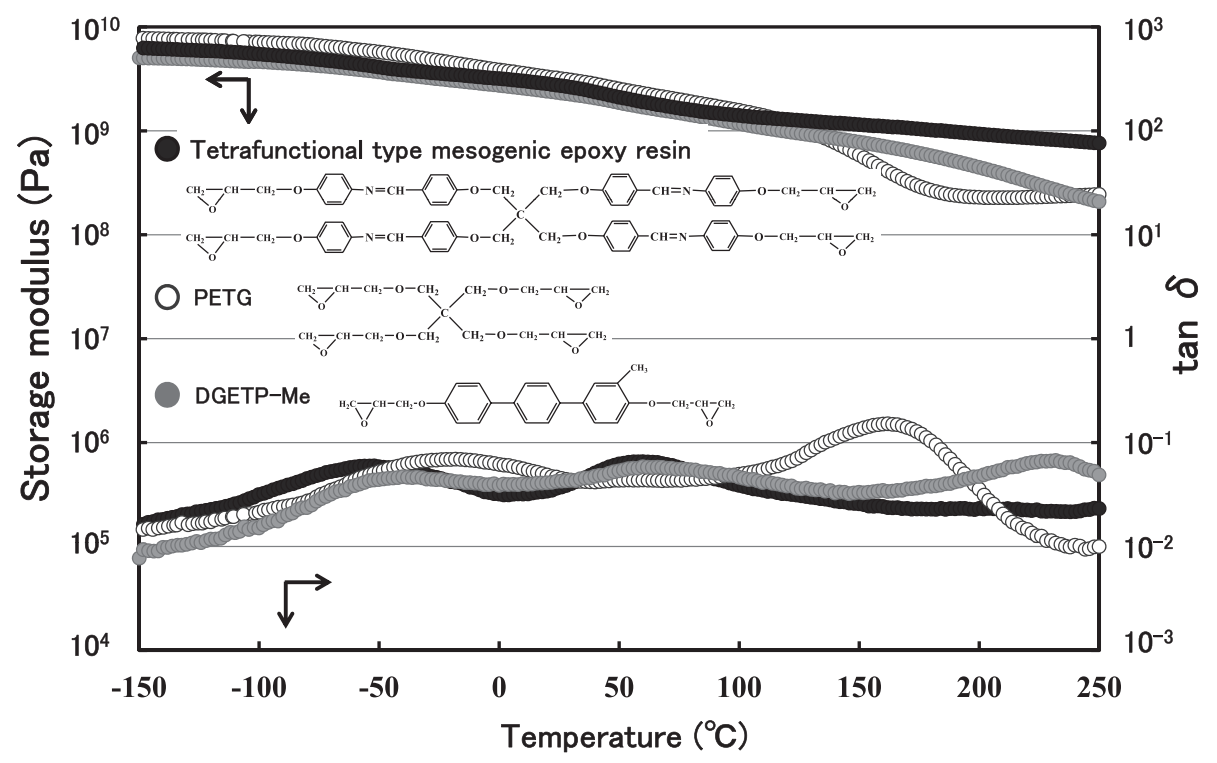

図 3. 4 官能型メソゲン骨格エポキシ樹脂の動的粘弾性挙動

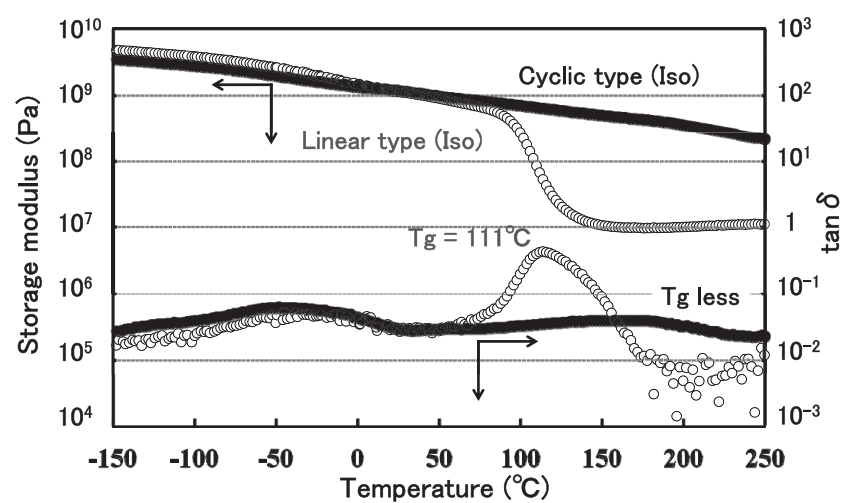

図 4. 環状および鎖状シロキサン型メソゲン骨格エポキシ 樹脂の動的粘弾性挙動

ラス転移温度に起因する $\tan \delta$ ピークおよび貯蔵弾性率の急 激な低下はほとんど観察されなかった。メソゲン骨格を持 たない 4 官能性エポキシ樹脂 (PETG) 硬化物や網目鎖中の メソゲン基濃度が同程度 (50 wt \% ) であるターフェニル骨格 エポキシ樹脂 (DGETP-Me) 硬化物と比較しても, $150^{\circ} \mathrm{C}$ 以 上の高温領域において高い貯蔵弾性率を維持した。分岐構 造の導入や架橋点の増加だけでなく, 剛直構造であるメソ ゲン基を共存させることにより, 網目鎖全体の分子運動性 が抑制されたものと考えられる。

また，骨格に環状シロキサンを導入することによって， エポキシモノマーの低融点化と硬化物の耐熱性向上を目的 とした樹脂の合成を行った ${ }^{24)}$ 。鎖状シロキサンを導入した 系では $\mathrm{Tg}$ が $104^{\circ} \mathrm{C}$ であったのに対し, 環状シロキサン系 では明瞭な $\tan \delta$ ピークは観察されなかった（図 4)。これ は, 環状シロキサン構造の導入による網目鎖の分子運動性 の低下や架橋点の増加による密なネットワークの形成に起 因するものと考えられる。また, 硬化物の引張試験を行っ たところ，破壊エネルギは鎖状シロキサン系と同程度を維

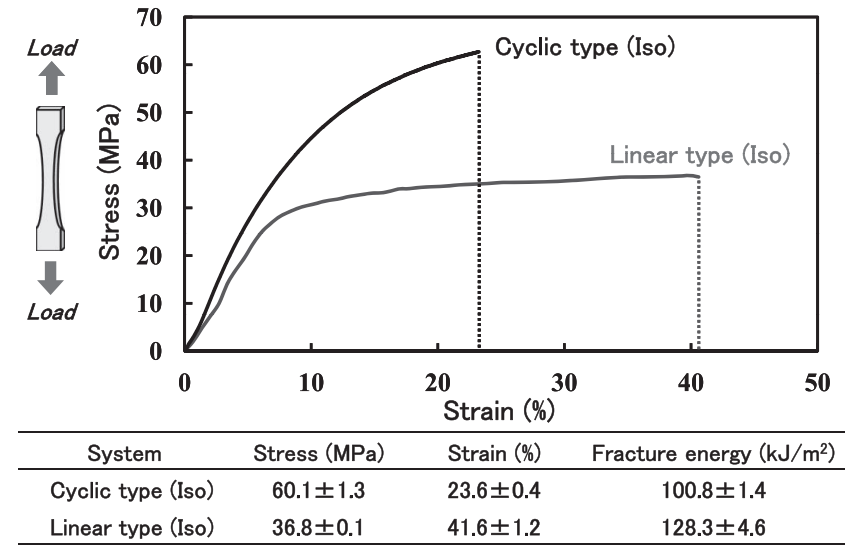

図 5. 環状および鎖状シロキサン型メソゲン骨格エポキシ 樹脂の引張試験

持した（図 5)。これらのことから，高 $\mathrm{Tg}$ と高強䩲性の両 立が達成された高性能エポキシ樹脂が得られたものと考え られる。

\section{6. おわりに}

エポキシ樹脂の硬化物中の網目鎖の配列性や導入する骨 格構造の変化によって, 硬化物の熱的・力学的性質の大幅 な改善が可能であることを紹介した。最終的な要求特性を 満足するためには，今後も多様な構造設計へのアプローチ が重要であると考えられる。

(2012.6.19- 受理)

\section{文献}

1) エポキシ樹脂技術協会：“総説エポキシ樹脂 基礎編 I ・ II , " 2003

2) A. Shiota and C. Ober: "Analysis of Smectic Structure Formation in Liquid Crystalline Thermosets," Polymer, Vol. 38, pp. 5857 - 
5867,1997

3) W. Mormann, M. Brocher, and P. Schwarz: "Mesogenic Azomethine Based Diepoxides-Monomers for the Synthesis of "Liquid Crystal” Thermoset Networks," Macromol. Chem. Phys., Vol. 198, pp. $3615-3626,1997$

4) W. Liu and C. Carfagna: "Synthesis of Liquid Crystalline Epoxy Oligomers: Effect of Molecular Weight on the Phase Behavior," Macromol. Rapid Commun., Vol. 22, pp. 1058-1062, 2001

5) H. J. Sue, J. D. Earls, et al.: "Fracture Behavior of Liquid Crystal Epoxy Resin Systems Based on Diglycidyl Ether of 4, 4'Dihydroxy-a -methylstilbene: Part II Effect Due to Blending with TACTIX 556 Epoxy Resin and Phenolic Monomers," J. Mater. Sci., Vol. 32, pp. 4039-4046, 1997

6) G. Barklay, C. Ober, et al.: "Liquid Crystalline Epoxy Thermosets Based on Dihydroxymethylstilbene: Synthesis and Characterization,” J. Polym. Sci. Part B: Polym. Phys., Vol. 30, pp. $1831-$ 1843,1992

7) M. Harada, K. Aoyama, and M. Ochi: "Fracture Mechanism of Liquid-Crystalline Epoxy Resin Systems with Different Phase Structures," J. Polym. Sci. Part B: Polym. Phys., Vol. 42, pp. 4044-4052, 2004

8) E. J. Choi, H. K. Ahn, et al.: "Liquid crystalline twin epoxy monomers based on azomethine mesogen: synthesis and curing with aromatic diamines," Polymer, Vol. 41, pp. 7617-7625, 2000

9) 原田美由紀, 松本真実, 越智光一, 山本久尚：“ッインメソ ゲン型エポキシ樹脂の熱的・力学的特性に与える柔軟鎖構 造の影響,”第 56 回高分子討論会予稿集, p. 4328, 2007

10) M. Harada, K. Aoyama, and M. Ochi: "Influence of the Loading Rate on Liquid-Crystalline Epoxy Resin Systems," J. Polym. Sci. Part B: Polym. Phys., Vol. 43, pp. 1296-1302, 2005

11) C. Ortiz, C. K. Ober, et al.: "Deformation of a Polydomain, Liquid Crystalline Epoxy-Based Thermoset," Macromolecules, Vol. 31, pp. $4074-4088,1998$

12) C. Carfagna, et al.: "The Effect of Prepolymer Composition of Amino-Hardened Liquid Crystalline Epoxy Resins on Physical Properties of Cured Thermoset," Macromol. Symp., Vol. 148, pp. 197-209, 1999

13) M. Harada, K. Sumitomo, Y. Nishimoto, and M. Ochi: "Relationship between Fracture Toughness and Domain Size of Liquid Crystalline Epoxy Resins Having Polydomain Structure, J. Polym. Sci., PartB; Polym. Phys., Vol. 47, pp. 156-165, 2009

14) M. Harada, N. Okamoto, and M. Ochi: "Fracture Toughness and Fracture Mechanism of Liquid Crystalline Epoxy Resins with
Different Polydomain Structures,” J. Polym. Sci. Part B: Polym. Phys., Vol. 48, pp. 2337-2345, 2010

15) B. Benicewicz, M. Smith, et al.: "Magnetic Field Orientation of Liquid Crystalline Epoxy Thermosets,” Macromolecules, Vol. 31, pp. $4730-4738,1998$

16) D. Ribera, A. Mantecon, and A. Serra: "Liquid-Crystalline Thermosets from Mesogenic Dimeric Epoxy Resins by Tertiary Amine Catalysis,” J. Polym. Sci. Part A: Polym. Chem., Vol. 40, pp. 3916-3926, 2002

17）原田美由紀，倉谷英敏，越智光一：“電場により配向制御し た液晶性エポキシ樹脂の熱機械的性質,”ネットワークポリ マー, Vol. 26, pp. 91-97, 2005

18) M. Harada, M. Ochi, et al.: J. Polym. Sci. Part B: “ThermalConductivity Properties of Liquid-Crystalline Epoxy Resin Cured under a Magnetic Field,” Polym. Phys., Vol. 41, pp. 1739-1743, 2003

19) M. Harada, M. Ochi, et al.: J. Polym. Sci. Part B: “Thermomechanical Properties of Liquid-Crystalline Epoxy Networks Arranged by a Magnetic Field," Polym. Phys., Vol. 42, pp. $758-765,2004$

20) M. Harada, N. Akamatsu, M. Ochi, et al.: "Investigation of Fracture Mechanism on Liquid Crystalline Epoxy Networks Arranged by a Magnetic Field,” J. Polym. Sci. PartB; Polym. Phys., Vol. 44, pp. $1406-1412,2006$

21) J. A. Dean: Lange's Handbook of Chemistry, 15th ed., McGrawHill, New York, 1999

22）原田美由紀，池尾康宏，越智光一：“低融点型液晶性エポキ シ樹脂の熱伝導性,”第 22 回 MES 論文集, pp.66-68, 2012

23 ) 原田美由紀，森岡大智，越智光一：“新規多官能性メソゲン 骨格エポキシ樹脂の熱的・力学的性質,”第 62 回高分子学 会年次大会予稿集, p. 652

24) 原田美由紀，横山宥吾，越智光一：“環状シロキサンを有す るメソゲン骨格エポキシ樹脂の熱的・学的性質, ”第 62 回高分子学会年次大会予稿集, p. 1021

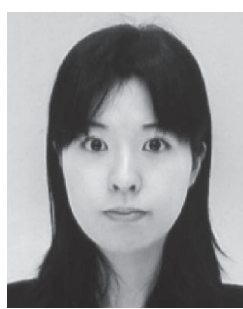

原田美由紀（はらだ みゆき）

著者紹介 関西大学 化学生命工学部 化学・物質工学科 准教授

(Department of Chemistry, and Materials Engineering, Faculty of Chemistry, Materials and Bioengineering, Kansai University)

干 564-8680 吹田市山手町 3-3-35

TEL : 06-6368-0731, E-mail : mharada@kansai-u. ac.jp 